\title{
THE WARSAW SCHOOL OF MARXISM
}

Maciej Gdula

University of Warsaw

Every student of social studies in Poland has almost certainly heard of the Warsaw School of the History of Ideas, whose members included, among others, Leszek Kołakowski and Jerzy Szacki. The school was important in Polish intellectual life both due to the high quality of its academic works and because of its members' ideological and political trajectories, which were typical for a large part of the Polish intelligentsia. Such a trajectory began with involvement in communist ideas and participation in building a new political order, then proceeded to revisionism - that is, a critique of the socialism that actually existed from the perspective of communist ideals - and finished with a rejection of totalitarianism and termination of any affiliations with communism or socialism. No one speaks of a Warsaw School of Marxism, although, as I will try to demonstrate, there are many arguments for considering that the people from Julian Hochfeld's circle, including Zygmunt Bauman, Jerzy Wiatr, Aleksandra Jasińska-Kania, and others, did comprise an academic school. I believe that distinguishing the school can shed a new light on the intellectual and social history of postwar Poland.

In discussions about the appropriateness of using the term "school" for the Warsaw School of the History of Ideas, attention is drawn to the non-existence of a founding manifesto, the lack of a common methodology linking the work of individual scholars, and the absence of anyone who could be recognised as an unquestioned leader with disciples (Bucholc 2013). However, the view prevails that Kołakowski, Baczko, Walicki, and Szacki nevertheless formed an academic school. Their common desire to study a diversity of philosophical and social doctrines, which were analysed in relation to the historical context, has been emphasised. Furthermore, the members of the school came from the same academic commu- 
nity (primarily the Faculty of Humanities at the University of Warsaw). Lastly, Kołakowski and others are recognised as members of an academic school due to their common historical experiences related to Stalinism, the breakthrough in October 1956, the events of March 1968, and finally the changes and conflicts of the 1970s and 1980s (Kołakowski A. 2013; Śpiewak 1981).

If these three criteria are applied to the people in Hochfeld's circle, then obviously we can speak of an academic school. Hochfeld's disciples were formed in the same academic environment; their fates were deeply connected to the course of political changes in Poland; and, in terms of their common intellectual points of reference, which stemmed not only from mere ideological but also conceptual relationships with Marxism, there is an even greater theoretical coherence than in the case of the Warsaw School of the History of Ideas. To these three criteria we can add Julian Hochfeld as a leader. He fulfilled an important role as a person who exposed young scholars to ideas from pre-war and international academic life, as the organiser of a standing seminar where research ideas and texts were discussed, and last but not least, as a source of intellectual stimulation and inspiration.

Of course, the value of the works created by the school members has been questioned. Jerzy Szacki, in the introduction to the important anthology Sto lat socjologii polskiej [One Hundred Years of Polish Sociology] declares authoritatively, in relation to the Marxists we are referring to and their work before 1968, that "the scholarly achievements of the sociologists-Marxists were not at that time particularly impressive [...] They were not, strictly, an academic school. The Marxists did not have a clear idea of sociology as a discipline, or of its relation to historical materialism, or any specific ideas for conducting their own sociological research" (Szacki 1995: 116). For Szacki - who in this place is not only an impartial historian of the discipline but also a representative of a competing academic school Marxism owed its position between 1956 and 1968 mainly to its political affiliation, and its main achievement was peaceful coexistence with other sociological paradigms in Polish sociology and resignation from exercising political force in academic discussions.

After a thorough examination of the works of the academics forming what I propose to call the Warsaw School of Marxism, it is difficult to agree with Szacki. Certainly, sociologists from this school remained closer to the party in a political sense (with exceptions, such as Zygmunt Bauman and Maria Hirszowicz in the 1960s and later), but it does not discredit their ef- 
forts to treat Marxism not as a dogma but rather as a living tradition that must be confronted both with changing social reality and with other scientific perspectives. The members of the school produced books of theory (Bauman 1964b; Hirszowicz 1964; Hochfeld 1982), empirical studies in the sociology of work (Hirszowicz 1967) and sociology of the nation (Wiatr 1969), and research on social structures (Wesołowski 1966). Sometimes the objection can be made that there was a gap between the high aspirations of the authors and the effects of their efforts, but it must also be remarked that representatives of the school wrote more than thirty books before 1968. Furthermore, when it comes to some of the works - for example, Wesołowski's Klasy, warstwy i władza [Classes, Stratas, and Power] (1966) - it cannot be denied that we are dealing with unique books which are among the handful of most important post-war achievements in Polish sociology and which set the framework for decades of research into the social structure in Poland.

It is not solely the derogation from dogma that constitutes the high value of the works produced in Hochfeld's circle but rather their manner of processing Marxist thought in a particular historical and political context. I therefore propose to talk about the Warsaw School of Marxism and not about "open Marxism," a term created by Hochfeld to establish the genealogy of his own perspective in the nineteenth-century historical materialism of Kazimierz Kelles-Krauss and used by people in his circle to define their intellectual positions (see, e.g., Raciborski 2007; Wiatr 1973b, 2017). Open Marxism suggests a distance from official Marxism and a positive interest in other theoretical perspectives and research orientations. At the time, the declaration of open Marxism was an important gesture of relinquishing the demand for exclusive access to truth on the one hand, and on the other, of signalling autonomy from the political power of the Party. Over time, however, it was interpreted primarily through the prism of the second part of the name, that is, the openness that signifies a departure from Marxism and readiness to mix it with other orientations. It is better to talk about the Warsaw School of Marxism by analysing how Marxist ideas were transformed by individual members of the school before 1968 and to search for Marxist elements in their intellectual biographies even after the events of that year.

The history of the Warsaw School of Marxism is an important supplement to the history of the Polish intelligentsia after 1945, going beyond the well-described trajectory of the circles for which Leszek Kołakowski was a symbolic figure - a trajectory which started with a strong commitment to 
building a new regime, then had its revisionist turn, and ended in radical criticism of real socialism from a liberal or liberal-conservative position (see, e.g., Gawin 2013; Król 2010; Siermiński 2016). In all important moments in post-war Polish history - including Stalinism, the period between October 1956 and March 1968, the 1970s, and the times of so-called transformation after 1989 - the paths of members of the Warsaw School of Marxism were distinctive.

\section{/// Julian Hochfeld - Intermediary, Master, and Organiser}

The Second World War, with the destruction of the country, the deaths of millions of citizens, the change of borders and political order, and the destruction of the former elites, made a dramatic break in Polish history. Nevertheless, when we look at the intellectual and academic elites, there was a significant level of continuity despite the severe war losses. In the case of sociology at the University of Warsaw - which was quite closely related to philosophy - the connections with pre-war academic life were very strong. Several important figures who mediated between the pre-war and post-war periods can be indicated: Tadeusz Kotarbiński and Władysław Tatarkiewicz, members of the Lvov-Warsaw School of Philosophy (Woleński 1989); Maria and Stanisław Ossowski, who were influenced by the latter school but developed their own project of humanistic sociology (Chałubiński 2007); and Nina Assorodobraj, a former student of Stefan Czarnowski, a thinker referring to the sociology of Durkheim (Czarnowski 2015). As Randall Collins demonstrated in his work on the sociology of academic creativity, the role of such intermediaries in the intellectual environment goes beyond the transfer of knowledge in the sense of passing on information. The role of masters is important when it comes to learning how to problematise academic matters and is crucial for building affective engagement in scholarship through rituals of discussion, spending time together, and enjoying collaboration (Collins 1998).

After 1945 Julian Hochfeld played this kind of role for young sociologists. He came from a well-to-do, educated family which had links, through his father, with the governing "Sanation" camp before 1939. In spite of these ties, young Hochfeld involved himself in the socialist movement while studying in Kraków and became one of the most active members of the Association of Independent Socialist Youth - the youth organisation of the Polish Socialist Party (PPS). He held both political and ideological functions in the organisation, engaging in disputes concerning the socialist 
party's strategy in regard to the Sanation government, the communists, the USSR, and the spread of fascism in Europe (Chałubiński 1991). Representing the radical wing of the party, he demanded a rapprochement with the Polish Communist Party (KPP) and a more explicit critique of capitalist reality. The successes of the popular front in France, which he followed while studying at the Parisian École de Science Politique, convinced him of the necessity of an alliance between the socialists and the communists. How hopeless those dreams were in regard to Poland was shown by Stalin's decision to liquidate the KPP in 1938 and by the wave of purges in the USSR, which cost the lives of many Polish activists of the communist movement (see, e.g., Shore 2009). Hochfeld tried to unite political activity and scholarship from the very beginning. Favourable conditions for this combination were created by the proximity of prominent scholars among his party friends: for instance, Oskar Lange, later a classic writer on the economy. In 1937, Hochfeld defended a doctoral thesis in statistics and economics, dealing with social security issues, a topic closely linked to the interests of the workers he wanted to represent by political activity.

During the war Hochfeld found himself in the USSR. With the Second Corps - a Polish military grouping formed on Soviet soil - he set off for the Middle East and ended his war trek in London, from where he returned to Poland in 1945 and immediately became involved in political and academic life. Until 1948 the political situation in Poland was far from unambiguous. There were legal political parties independent of the new communist Polish Workers' Party (PPR); the authorities were making conciliatory gestures toward the Catholic Church, and sought to win the favour of some of the intellectual elites by organising a "Democratic Professors' Club," a gathering of progressive-thinking academics who were not necessarily of communist and Marxist orientation.

In this atmosphere, an important discussion on Marxism between Stanisław Ossowski, Julian Hochfeld, and Adam Schaff took place in the journal Myśl wspótczesna [Contemporary Thought]. The starting point for the discussion was a text by Ossowski (1970 [1947]), who belonged to the tradition of the left-wing, non-communist intelligentsia. He wrote that there was no cooperation or will to understand each other between Marxists and representatives of other intellectual perspectives. Marxism, Ossowski argued, had to reach for new scientific methods and to become a "movement factor" instead of repeating old nineteenth-century formulas. He also expressed the hope that the introduction of Marxism to universities would be an attack on ignorance rather than on scholarly criticism and that Marxism 
would treat capitalist and socialist reality symmetrically, as orders requiring thorough investigation and criticism (Kraśko 1996: 113-114). Marxism, instead of adopting a rigid attitude in the struggle for power and perceiving every criticism as an attack on its doctrine (treated with almost religious celebration), should be open to debate and should explore changing conditions by new scientific methods. For Marxism in the socialist countries, the choice of such a path meant active participation in changing social conditions step by step. According to Ossowski, this would resemble the role of Marxism in the West, where it was used to critique existing institutions and contribute to partial rather than revolutionary changes. The post-war transformation in Poland - Ossowski pointed out - was far from having a revolutionary dynamic and the Marxists could not ignore that fact.

The text was answered by two intellectuals of the Marxist orientation. Adam Schaff, who was attached to the PPR and represented Marxist orthodoxy, attacked Ossowski for questions striking at the essence of Marxism (Schaff 1948). Since he draws attention to the dual character of Marxism - scientific and political - and Marxism rejects the duality of theory and practice, the adoption of Ossowski's perspective would equate to a death sentence for Marxism. According to Schaff, presentation of the materialistic view as a religion is characteristic of sociology and leads to a confusion of concepts, creating a convenient point of reference for a "reaction" that represents the religious and the materialist worldview as two identical phenomena. According to Schaff, Marxism by definition is anti-dogmatic, so any concern that it clings to doctrine is unreasonable.

Hochfeld criticised Ossowski in a polemical but much more favourable manner. Hochfeld argued that the things Ossowski criticised in Marxists - such as dilettantism, ignorance and presumption - could be found in every academic and theoretical movement; they were not restricted to Marxism but were common phenomena (Hochfeld 1982b [1948]: 60-61). For Hochfeld, Marxism belonged to the fabric of modern science, which meant accepting the material nature of the world and exploration of the interdependence between phenomena and the search for causalities. The dispute between the Marxists and the representatives of other orientations is not so much about the method but rather about the emphasis on certain subject matter. Marxists focus on investigating the transformations of productive forces and the material side of social processes. From this polemic the principles of Hochfeld's programme of Marxist sociology can be derived: it is based on empirical research and critically complements the findings of other perspectives of a more "idealistic" character. 
Hochfeld's position may be surprising given how quickly he became one of the scholars involved in the reconstruction of Polish scholarship in accordance with the Soviet model, including the removal of sociology from the university as a bourgeois science. Understanding this turn requires taking into account the specificity of Hochfeld's participation in Stalinism in Poland - a participation that does not fit in the dominant interpretation of the involvement of intellectuals in communism as proposed by Czesław Miłosz in the Captive Mind. For Miłosz, fascination with communism was a derivative of secularisation and the search for a new guiding principle for organising the world. Intellectuals were supposed to be particularly vulnerable to the charm of this doctrine; it was a system complex enough to entice educated people, to give them a sense of contact with the masses and hope for a just order built by state structures. This combination proved so appealing to people of culture and science that they were completely absorbed in Marxist theory and Stalinist practice. Although this explanation - especially when it comes to the fervour of faith and sense of power connected with proximity to the state apparatus - provides an explanation for the attitude of the younger generation (people born in the late 1920 s and early 1930s, called the "spotty Stalinists"), it does not enable an understanding of how people such as Hochfeld came to be enrolled in Stalinism.

To elucidate the question one has to reconstruct the political context of the post-war period, when after a few years of coexistence it became clear that Stalin's tolerance was over for the parties not controlled by communists in the countries subordinated to the Soviet Union. In Poland, communist dominance was to be realised by unification of the communist PPR and the socialist PPS, which was still independent from Moscow. Although at the end of 1947 the Socialist leaders asserted that the PPS was needed in Poland as a separate party, in the following year they became advocates of unification (Grochowska 2014: 206-208). This did not mean that they underwent a radical conversion, but rather that they had bowed to necessity. In the records of the PPS Central Executive Committee from this period Hochfeld argued that consenting to unification was the only chance of avoiding unpredictable conflict and playing a role in the new political structure. He was fully aware that the intentions of the party's opponents were not pure and that they retained the advantage of controlling the state apparatus. Nevertheless, he thought that starting to work with them was a better option than making a romantic gesture of refusal (Grochowska 2014: 192-193). 
The dynamic soon moved from the political field to other areas of life. In 1949 the authorities demanded a diminution of the non-Marxist professors' influence on academic life and a limitation of their contact with students. The impartiality and neutrality of scholarship was attacked as an expression of reactionary thinking, hostile to the logic of socialist change in Poland. In connection with academic life, the culminating moment of Stalinism was the First Congress of Polish Science in 1951, which condemned non-Marxist scholarly currents and expressed support for the reorganisation of academia according to the Soviet model. At the congress, Hochfeld and Assorodobraj emphasised that sociology and Marxism were two separate lines of development in scholarship, and only the latter was progressive (Kraśko 1996: 136). With the academic year of 1952 a reorganisation of teaching in higher education began. Sociology at the University of Warsaw was liquidated and in its place Marxist chairs were instituted and taken by Hochfeld and Assorodobraj. Maria and Stanisław Ossowski, although they maintained their offices and workplaces, were kept from teaching. Sociology as a lecture subject returned to the university only four years later, in 1956.

Quite soon it emerged that even the moderate hopes of Hochfeld for shaping politics in the Polish United Workers Party (PZPR) - a new party formed after the unification of the PPS and PPR - turned out to be unrealistic. The party was monopolised by communists close to Moscow, and Hochfeld himself was systematically marginalised and his real influence on politics was negligible, although he remained a member of parliament and for some time was a deputy member of the Central Committee (a highranking party official). Even though the changes to which he contributed in academia were short-lived, they left a mark on sociology by limiting the debate between scholarly currents: what was involved was an abuse of political power in academic debates (see Kilias 2012). Hence, in Polish sociology after 1956, various paradigms existed side by side, avoiding open confrontation (Szacki 1995). Interestingly, contrary to Ossowski's predictions, this did not lead to the ossification of academic schools.

In the case of the Warsaw School of Marxism it was not without significance that Hochfeld, being deprived of political influence, was increasingly devoted to scholarship. After 1956 he promoted three young doctoral students: Zygmunt Bauman, Maria Hirszowicz, and Jerzy Wiatr. He created the only academic journal in the communist countries to be devoted to sociological research into political systems: Studia Socjologicæno-Politycæne 
[Sociological and Political Studies]. This journal was one of the institutional pillars for the school and published articles and books by members of Hochfeld's circle. During its existence between 1958 and 1968, twenty-five issues were produced; they included texts devoted to such non-orthodox Marxist topics as British socialism, public opinion, and local elections. Another institutional pillar of the school was a seminar led by Hochfeld. During the seminar his collaborators presented the findings of their research and investigations and had an opportunity to openly discuss scientific and political problems. The atmosphere and high standards of the discussions attracted important figures of Warsaw's academic life, such as Jan Strzelecki, Tadeusz Kowalik, and Adam Przeworski, who did not have professional connections with Hochfeld (Jasińska-Kania 2007: 370). Hochfeld's intellectual and organisational skills led to the rapid formation of a group of scholars who collaborated even after he went to Paris in 1962. There he worked in a UNESCO committee and died in 1966, just before his intended return to Poland.

Hochfeld's scientific activity after 1956 should be placed in the full picture of his life, which was marked by constant political disappointments and, nevertheless, efforts to improve the social world. Regardless of the significance of his activities during the Stalinist period and the assessments that may be made of his role in the academic world at the time, Stalinism was only one stage in his life, not the moment that defined his identity. This was the difference between him and the "spotted Stalinists," for whom involvement in Stalinism was key to their generational experience and later defined their way of viewing the world and subsequent conversions. Hochfeld did not depart sharply from his previous ideas and convictions about the need for a deep redefinition of the socialist project. On the other hand, he did make efforts to influence the shape of the existing social system - mainly to preserve some democratic elements, both in the form of civil rights and in regard to the people's influence on social life.

Hochfeld's reflections on parliamentarianism (1982c [1957]) should be analysed from this perspective. The point of departure for him was to compare the system of democratic centralism - that is, the model of Bolshevik politics - with parliamentary democracy. According to Hochfeld, the specificity of the former was a prerequisite for radical social change in a backward and isolated country such as Russia in the early twentieth century. Only the determination of the centralised leadership, controlling the political, administrative, and economic power, could change the course of 
social processes. The party's elitist character was supposed to protect the organisation from involvement in the existing order and reproduction of its elements. Yet the fate of democratic centralism provided an ambivalent picture: the system had managed to stabilise, but the consequences for democratic latitude had been significant.

On the other hand, there was parliamentary democracy in the Western style. Hochfeld noted at the time that scarcely anyone considered it to be a system in which the citizens simply ruled. Rather, what was involved was a complex system in which the bourgeoisie, because of its dominant position, managed to control many areas of social life. However, it could not be considered that parliamentary democracy was a mere illusion. The ability to vote had been won by the workers' movement, and the existing workers' parties, even if they were not revolutionary, could act as a counterforce to the bourgeoisie, which was not free to impose its interests. Institutions were not an emanation of ideas; they were an effect of forces but also had some autonomy.

In Poland - Hochfeld pointed out - there could be no Western-style parliamentarianism as it would mean turning away from the reform process and disregarding the international situation. However, efforts should be made to develop institutional solutions that would limit negative trends within the socialist state. There was no question of limiting the PZPR's leadership. However, parliamentary autonomy could be increased to counterbalance the Central Committee. This did not mean the establishment of an internal opposition, but that the parliament must be more than a place exercising the will of the party - MPs should have autonomy in their discussions, comments, etc. Such a parliament should work within a system of "checks and balances."

Hochfeld's investigations lack deep reflection on the issue of the masses' representation by the party. He thought that the existing mechanisms of functioning should be improved, but he also assumed that the party represented the interests of the working class. There was no answer to the question (Marxist in principle) of what kind of forces lie behind parliament in a socialist state. The idea that there was thus a conflict of interests would have been considered revisionism and an attempt to undermine the existing political order. Hence, Hochfeld departed from Marxist schemes of analysis and reached for liberal "balance of power" concepts; he advocated for institutional solutions designed by intellectuals and accepted by the party. The theoretical inconsistency can be seen, but it comes directly from 
the structure of the situation in which Hochfeld found himself. On the one hand, his Marxist affiliation and professorship gave him a certain influence and the right to speak on public matters; on the other, there was a thin line beyond which one became an enemy of the system, even if Marxist rhetoric were used. This was the case with Karol Modzelewski and Jacek Kuroń, who wrote the famous "Open Letter to the Party" (2009), criticising the existing social reality from the position of Marxist revisionism. As a result, they were expelled from the Party and sentenced to prison in 1964. Hochfeld and his disciples, at least until 1968, would move in the space between official Marxism - which confirmed mono-party leadership as an embodiment of progressive currents - and a revisionism that critiqued the existing socialist system from Marxist positions and fidelity to communist ideals.

In this space, the project of critical social science was not rejected but built on the basis of elements drawn from various intellectual traditions. References to the liberal idea of checks and balances should not be interpreted as an abandonment of Marxism, or selective use of it only in order to criticise the capitalist order, but rather as a search for various tools to critique a system in which the state exercised both economic and political power.

Hochfeld's constant use of Marxist elements to criticise socialism is confirmed by his book Studia o marksowskiej teorii spoteczeństwa [Studies in Marx's Theory of Society] (1982d [1963]). To see how the book uses Marxist notions to construct the foundations for a critique of socialist societies it is worthwhile to focus on the problems of work and alienation. Hochfeld asks about working conditions in today's societies, that is, whether the unprecedented growth of productive forces was related to the humanisation of work. The issue must be considered by reference to the industrial system and not to the type of ownership or organisation of the political world, which makes the question common to capitalist and socialist societies. Reflection on the issue requires a return to Marx's classic works and the traditions of reform movements.

Marx's hope was for the complete abolition of alienation, and the establishment of unity between human nature and real humans, through a revolutionary change that primarily involved social ownership of the means of production. In the tradition of reform movements, it was assumed that reducing alienation by making partial changes - limiting working hours and extending free time - was possible. This would extend the boundaries of the "kingdom of freedom," which was nonetheless built on 
the "kingdom of necessity," a prerequisite for social reproduction. In the latter case, the stake was not so much a change in the form of ownership of the means of production but rather in the form of organising labour relations. This is a problem both in socialism and capitalism and involves the actions of various social actors: from the revolutionary activities of the workers' movements, through the reformers, to the activities of actors "competing against the workers movement" (ibid.: 637).

Although the volume of production had changed tremendously in the middle of the twentieth century and the level at which needs were satisfied had increased, work remained mainly standardised, industrial work, subject to even greater rationalisation and control (ibid.: 648). To these could be added the ongoing standardisation of management and design activities. The growth in labour productivity could partly be seen as an optimistic sign, but it must be remembered that productivity growth is accompanied by a parallel increase in social needs and the cost of collective consumption. These include health and education, as well as administrative support and defence expenditures, giving rise to justified criticism from people producing goods in industry (ibid.: 652). Although more goods are available to satisfy important needs, new products of control and alienation are created simultaneously with their production (ibid.: 653). The masses can be manipulated by the mass media and indulge in mindless entertainment. When the peak of aspiration is to have a radio, a television, a refrigerator, or a car, a person is reduced to his needs and separated from the ability to create, develop, and cooperate with others.

Recognising the emergence of post-war mass societies, Hochfeld went along with such contemporary theorists as Mills (1951), or Adorno and Horkheimer (2002 [1947]). He saw the project of sociology as a constant confrontation of the legacy of the critical tradition with historically changing social reality in order to grasp the dependence, domination, and alienation reappearing in new forms. It is possible to say of Hochfeld that in his criticism he remains abstract and does not cross the line to deliver a concrete critical analysis of socialist societies. On the other hand, by locating the problems of the industrial order and work in both socialism and capitalism, he was opening the prospect that all the inconveniences of capitalism were at the same time the inconveniences of socialism. In the 1960s, his project of creating an empirical Marxist sociology that could somehow be critical of social reality under socialism was completely unique in all the countries under Soviet influence (Kilias 2017: 58-59). 


\section{/// Defense and Internal Criticism of Socialism - Hochfeld's Circle before 1968}

Whereas the absence of explicit empirical references to the reality of socialist societies may be regarded as an understatement in Hochfeld's writing, a similar allegation cannot be made about one of his heirs, Włodzimierz Wesołowski. He linked Marxist theoretical and political perspectives with modern positivistic research methods, which he assimilated during a scholarship in the US, where he had the opportunity to collaborate with Lazersfeld, Lipset, and Bendix (Sułek 2011: 126). This combination produced an interesting effect in the book Klasy, warstwy $i$ wladza [Classes, Stratas, and Power], which is a combination of theoretical considerations and an interpretation of empirical research.

Understanding the full background of this book requires recalling a point of reference that will not be found in its footnotes: namely, the revisionist tradition. This is an obvious intellectual standpoint for Wesołowski's criticism - although he does not get into a direct polemic due to fears of official repercussions. In the 1960s, when Wesołowski was working on his book, revisionism in Poland was represented by Kuroń and Modzelewski, the authors of the above-mentioned "Open Letter to the Party," which inspired radical circles on both sides of the Iron Curtain. In the "Open Letter," the party bureaucracy is interpreted as a new ruling class, whose interests are at odds with the interests of the workers. The party bureaucracy was striving to expand its power by increasing the scale of investment at the expense of consumption. Conflicts of interest, however, were leading to constant tensions between the workers and the party, which would end with a revolutionary explosion and the establishment of a real workingclass order. This would be neither a bourgeois democracy nor a dictatorship of the bureaucracy, but a democracy realised by the workers' councils. Wesołowski's analysis is a polemic with this perspective and an attempt to provide legitimacy for the existing socialist order.

An alternative revisionist to Wesołowski was Bronisław Minc, a former officer of the Central Planning Bureau and an economics professor, who proposed that socialism should be analysed through the prism of the conflict between the state and cooperative sector (see Tellenback 1975). Wesołowski accused Minc of formalism, which in the Marxist dictionary, was naturally the worst of insults. It was unacceptable to assume, as Minc was doing, that the form of property itself determines the conflict, and to disregard the fact that workers hired in each of the sectors had opposing 
class interests. According to Wesołowski, Minc's proposal was too static and did not take into account what was really happening in socialist society, that is, the gradual abolition of class differences.

An analysis of socialism must take into account the difference between capitalism and socialism. In capitalism, relationships between classes are determined by their relationship to the means of production. In socialism, classes in these terms disappear as well as the antagonism between them. This does not mean, however, that there is no such thing as a social position. After all, workers do physical work and work in an industry. They also receive a certain income and have a certain education, attitudes, and lifestyle.

The position of the workers must be investigated in relation to representatives of other strata of socialist society, that is to say, the intelligentsia and small-scale producers not hiring workers. In capitalism, the intelligentsia can occupy an ambiguous position in regard to class conflict, because it is not a class but a strata. In socialism, the intelligentsia differs from workers by education, kind of work, income, and prestige, but it becomes equated with workers as a strata. Small-scale producers, in turn, are sometimes defined as a class and sometimes not. The reason for treating them as a class involves the means of production - they are the owners. Against this standpoint, the argument can be brought that as they do not employ workers they do not exploit and control the work of others. They also do not have the power to create their own social formation. Here Wesołowski evokes Hochfeld, who referred to small-scale producers as the defective class. Farmers, counted as small-scale producers, are a special case. In the context of the socialist state, there was a visible effort to integrate them as deeply as possible into the socialised economy and to equalise their life chances - by organising machinery parks and agricultural circles, and by care for their children's education, which would further reduce their possible distinctiveness as a class.

Relations between the strata in socialism must be analysed by distinguishing the factors of social position: the kind of work, income, education, and prestige. There are two ways to describe the stratification associated with these factors. First, the degree to which certain attributes were distributed in the population should be investigated, and second, the relationship between the attributes must be grasped. Wesołowski observes - and it should be considered a significant contribution to analysis of the system of real socialism - that the transformations in socialist countries had led to the decomposition of stratification factors. This implied, for example, that 
some of the groups with lower education were able to achieve substantial incomes. Wesolowski's theses are based on empirical data and research findings. He mentions that before 1939 every non-physical worker earned a better wage than a physical worker, and the wage of the former was two times higher than that of the latter. By the 1960s the situation had changed: $30 \%$ of physical workers earned more than $60 \%$ of non-physical workers, which indicated the decomposition of income and work factors. Another type of decomposition was related to work and prestige. Research into the prestige of occupations showed that some of physical-labour occupations, such as steel-working, enjoyed higher prestige than, for example, the occupation of an accountant. Wesolowski notes that in capitalist societies some stratification factors are also decomposed, but the scale of the decomposition is incomparably smaller than in the socialist countries.

The greater egalitarianism of socialist societies does not mean that no tensions are present. The fact that socialism does not rely on the market and the state allocates social resources and decides on the distribution of income leads to a situation in which the conflict is no longer a struggle between social groups but becomes a conflict with the state. In socialism there are also other types of conflict not related to income distribution. For example, conflict exists between the intelligentsia and the peasants and physical labourers for access to education. The former demand affirmative action and the latter are in favour of "purely meritocratic" criteria. While the contradictions of capitalism lead to a conflict that abolishes capitalism, tensions in socialism do not have that effect. People accept how social goods are distributed because it is just and a development toward even greater justice.

The fact that socialism derives its legitimacy from the promise of a transition to communist society leads Wesolowski to reflect on political power guiding social development. Wesołowski proposes a distinction between governing and ruling. Both in capitalism and socialism there are people who govern because that is their profession and such are the "functional requirements" of social systems. However, it is less important who governs than whose rule is expressed by this governance. The question is whether it is possible to speak of "ruling" in socialism when society is classless. In socialism no class controls the means of production and uses the state to safeguard its interests. The social product goes straight to society. But it can be said that the working class is the ruling class in socialist society for three reasons: maintenance of the socialist state is in its interests; its party protects this system; and the system is sanctioned by the 
working-class ideology. In the long run, the working class will no longer rule and power will become "socialised."

For Wesołowski in the 1960s, two ideas were not subject to discussion. First, the working class was the progressive class, that is, the class whose rule would lead to the desired social change and the transition from socialism to communism as the embodiment of a just society. Second, the interests of the working class as a progressive class were represented by the party, which retained a leading and unquestioned role in conducting social change. On the one hand, this approach opened the way to bolder empirical study of social relations in socialism, including social conflicts, but on the other hand, the critical power of these studies was weakened by considering certain conflicts to be insignificant due to the logic of social development.

A slightly different view of sociology in socialism appears in the writings of Zygmunt Bauman. In the Warsaw School of Marxism in the 1960s they stand as a specific reversal of Wesołowski's proposals. Bauman made rather little use of empirical sociology (in connection with his distanced approach to positivism) and was more in favour of abstract reflections. At the same time he remained a proponent of a critical approach toward socialist society. It is worth pointing out that both Wesolowski and Bauman worked within the limits sketched earlier in the case of Hochfeld; that is they did not question the leading role of the party in socialism and rejected revisionism.

The book Wizje ludץkiego śniata [Visions of the Human World] (1964a), which is devoted to the relationships between knowledge and the changing social ground, can serve as a good example of Bauman's work from this period. At the outset of the book Bauman notes that the social sciences were born with the crisis of faith in the marketplace, the factory, and technological progress as a means to progress and prosperity for all mankind (ibid.: 12-14). The social sciences were driven by the hope of creating a more predictable order and of gaining control over chaotic and destructive social forces. Although some scholars believe that this type of knowledge can be built by introducing impeccable empirical approaches and extensive research by mathematical methods, this is a perspective that ignores the social foundations of knowledge production. The multiplicity of paradigms, which appeared in sociology from the outset, resulted from the heterogeneous nature of social reality itself. It is a man-made environment that mediates the human relationship with nature, but at the same time the social world is subject to objectivisation and operates according to 
its own rules, which permanently divide people and oppose them to each other (Bauman 1964a: 19-21). Unifying knowledge would only be possible in a situation of far-reaching unification of the social world, which did not seem likely in the close future.

Diversity of knowledge is not limited to the coexistence of a plurality of theoretical perspectives but also encompasses different ways of using knowledge, which Bauman differentiates as engineering by rationalisation and engineering by manipulation. The first is to create knowledge that gives different groups a more appropriate picture of the situation and enables efficient action. The role of such engineering is well defined by Gramsci - it is a kind of theory that converges and intersects with specific moments of history to make the action more homogeneous and coherent. In this situation the theory intensifies practice (Bauman 1964a: 39). In a given period, different systems of knowledge are competing, and the one that prevails is better suited to the specific historical situation of the masses, allowing them to identify their goals precisely and carry them out more effectively. The second type of use of social knowledge is engineering by manipulation. It is the knowledge of human activities that is at the disposal of the elite and is used to direct the activity of the masses. It manifests itself by setting certain parameters to a situation in order to induce people to action that is not favourable to them and serves the interests of the elite.

In socialism, due to the abolition of formal and actual class divisions, there are no social conflicts that must be engineered by rationalisation. Socialism can be compared to a mammal that is equipped with a central nervous system. Capitalism, in turn, is like an annelid. The individual segments work to some degree independently of each other. The problem of socialism's proper functioning as an organism is connected with the effective functioning of the centre. This involves the need to adequately diagnose complex social processes and make decisions that help to reduce alienation. An empirical sociology plays an important role in this process (Bauman 1964a: 556). The lack of discussion on the usefulness of specific theories and doctrines may lead to actions inadequate to the status of social actors and consequently to violence, as happened during Stalinism (ibid.: 550).

For Bauman, sociology's role in socialism is certainly not about designing a new political order, or holistic social criticism. This does not mean, however, that sociology becomes merely a narrow-minded discipline supporting technocracy. The socialist order creates its own forms of alienation and the role of the social sciences is to discover and propose remedies. A number of perspectives appear to be prerequisite for effective coping 
with the negative phenomena emerging within socialism. Although Bauman accepts the central role of the Party as the main political principle, he clearly advocates a division of power in the creation of knowledge about the social world and the formulation of reform projects.

Bauman's caution in confronting the party was rooted not only in general acceptance of the direction of developments in Poland, but also in the fear of the possible consequences of open criticism. To what degree Bauman's fears were justified was soon to be revealed, after he defended the students against repressive power in connection with the publication of the "Open Letter to the Party." From that moment on, he began to be perceived as a dangerous revisionist and subjected to the surveillance of the secret police. Later, matters took a more dramatic turn. During the March events - a political crisis in 1968 that ended as an anti-Semitic and antiintelligentsia campaign organised by the party - Bauman was portrayed as one of the symbols of "revisionism" and expelled from the university, along with Leszek Kołakowski, Włodzimierz Brus, and Maria Hirszowicz. Repression of academic and cultural elites acquired much more brutal forms than in the 1950s. Soon members of the Warsaw School of Marxism - Zygmunt Bauman and Maria Hirszowicz - would be forced to leave Poland (like thousands of other Poles of Jewish descent). Of course, this meant breaking the close ties between school members and the end of intensive cooperation between them, but the story of the school does not end there. The way its representatives reacted to the changing conditions is significant and retains a "family resemblance."

\section{/// Towards an Active Society - Disciples of Hochfeld after 1968}

In the film by Andrzej Wajda, Man of Iron, one of the most influential movies on modern Polish history, March 1968 and December 1970 are depicted as involving the unhappy desynchronisation of social protests. When the students protested, the workers did not respond. When the workers protested, the intelligentsia was silent. During the 1980 strikes, the two kinds of protest combined and consequently there was a resounding social revolt, as a proper objection to one-party rule. In that interpretation, the decade of the 1970s was just an interlude between the waves of social protests and the period of waiting for the "inevitable." In fact, the reaction to the events of March and especially of December 1970 was very profound and brought significant changes to the functioning of the social order, as was also reflected in the works of the Warsaw School of Marxism. 
It is worthwhile to begin by looking at the evolution of Wesołowski's views. Just a few years earlier Wesołowski had sought legitimacy for socialism by demonstrating that the socialist system is the most efficient in implementing the ideals of equality and that the party guarantees social development and the representation of workers' interests. In a text written less than a year after the December events of 1970, he advocates that workers must be allowed to participate in setting the country's economic policy and production goals in companies. People who speak of the necessity of enlightening the masses or deciding on behalf of backward citizens are defined by Wesołowski as conservative and anti-modern (Wesołowski 1974). Belief in the party's leading role is marginalised by the hope that socialism can be revitalised by the bottom-up activity of the workers. Importantly, this change took place in a relatively short time and its direction is characteristic of the changes to Polish culture, science, and politics that would set the dynamic of the next forty years.

The writings of other representatives of the Warsaw School of Marxism fit in the new cultural framework. The differences between their writings allow us to see how they shaped this framework by reflecting on modernisation and its perils without reference to the historical mission of the working class (which still resounds in Wesołowski's texts).

In the texts of Jerzy Wiatr, one of the most productive and institutionally important members of the school, we can easily trace the change in how he dealt with the question of the political dynamics of socialist societies in the 1960s and 1970s. In his influential book, Czy zmierzch wieku ideologii? [The End of Ideology?] (1968 [1966]), which was praised by the Polish Academy of Sciences and reprinted, Wiatr engages in polemics with Raymond Aron's and Robert Lipset's ideas about decreasing the role of ideology in modern, post-war societies. As an intellectual representing the socialist world, Wiatr criticises the assumed disappearance of ideology in the Western capitalist states, pointing out the existence of communist parties in some capitalist countries, such as France and Italy, and emphasising the role of anti-communism as an ideology in the USA. In contrast, Wiatr declares the existence of a socialist ideology in the East, founded on ideas of equality, social justice, collective property, and the authority of the people. This ideology is supposed to unite different strata in the effort to finish the revolutionary process under the guidance of the party. Wiatr's perspective of the 1960s is still highly concerned with Cold War division and competition. 
In articles published at the beginning of the 1970s Wiatr focuses not on ideology and revolution but on the participation and autonomy of different levels of political organisation (Wiatr 1973a). The dynamics of socialist societies are analysed from the perspective of modernisation - which means both the development of industry and urbanisation, as well as increased participation in the party, various social organisations, and electoral activity. The relations between modernisation of the means of production and social participation are analysed empirically to create knowledge that could be used to deepen the autonomy and responsibility of social actors (Wiatr 1973a: 20-24). This perspective is also present in Wiatr's more detailed and technical considerations on local governance. He postulates broadening the autonomy of local authorities in order to encourage individuals, as citizens, to organise their immediate social environment (Wiatr 1973a: 113). The former flame of ideological confrontation and collective revolutionary mobilisation that appeared in Czy zmierzch ery ideologii? [The End of Ideology?] had given way to a pragmatic attitude and the will to create a space for social activity that is not defined in terms of one collective aim.

Among the new topics that were extremely important in a changing cultural context were the questions of organisation and management. They were interestingly addressed in the writings of Witold Morawski, one of Maria Hirszowicz's students. Significantly, in the 1960s Hirszowicz and Morawski jointly researched workers' councils, which emerged after 1956 as a means of self-organisation (Hirszowicz \& Morawski 1967). Morawski himself was involved in research on industrial relations in the USA, analysing, among other things, the mechanisms of conflicts and their institutionalisation, and criticising business ideology (Morawski 1970). A few years later he modified his interests, turning to the subject of management and organisation in the belief that knowledge of these areas was crucial for understanding Polish conditions and formulating development projects for socialist society.

He reflected, for example, on the subject of industrialisation. He noted that this process had been analysed through its effects, such as how local labour markets change, how workers behave, how a city alters after a large factory is built, and so forth. As a change of scope, he proposed distinguishing between development processes and organisational mechanisms. This proposal showed the need to grasp the complexity of social processes. Morawski noted that socialist industrialisation was strongly linked to the doctrine of satisfying the needs of the people, enlarging the working class, and overcoming underdevelopment. Nevertheless, in the previous stages 
of industrialisation, significant decision-making errors had been made. For example, after 1956 a very low level of consumption was maintained in order to accelerate the pace of investment. Referring to the 1970s, Morawski stated that the new party team had a different vision of development. Instead of economic growth it spoke of socio-economic development, which has not merely a quantitative but also a qualitative aspect. Industrialisation had been imposed in the 1950s and 1960s. The goals were defined by planners; changes were rapid and controlled by the central bureaucracy. This strategy was effective, but only when a non-complex economy was being built. Complex industrialisation needs more bottom-up activity and innovations. This is where Morawski's radical switch of perspective takes place. It is not that industrialisation generates modern society, but rather that a modern, active, and innovative society is a condition for development and industrialisation. This creates a need for the economy to be de-bureaucratised, for increased consultation, stronger links with Western countries, the purchase of licenses, and consideration of change as a permanent part of the planning process. The barrier to such development is the continuous dominance of politics over the economy in socialism; according to Morawski, such dominance should be limited.

A slightly different theme appears in Aleksandra Jasińska-Kania's works, but they also fit in the new cultural framework of an active society. In the 1960s, Jasińska-Kania explored issues of politics and alienation in Marx, in order, in the 1970s, to address questions of personality and attitudes. With Renata Siemieńska, Jasińska-Kania wrote Wrory osobowe socjalizmu [Personality Patterns of Socialism] (1978), a book in which the historicisation of socialism itself is clear. The analyses are not based on a division between the new order as opposed to the old one, or on the Cold War perspective of opposing socialism to capitalism (Jasińska-Kania \& Siemieńska 1978, see, e.g., p. 318). Based on party documents, popular culture, and research on attitudes and values, the book presents the evolution of socialism itself.

Jasińska-Kania and Siemieńska showed, for example, how the heroes of novels had undergone transformation. In the days of socialist realism, the hero was either a worker or a party activist taking up the fight for a new order. In the period after 1956 only 18 out of 81 leading characters in the novels they studied were workers; in almost $40 \%$ of cases, the readers were not given much information about the characters' class or occupational origin. Instead, emphasis was placed on the individual's experience of interpersonal relations. In the 1970s, more emphasis was placed on the 
de-idealisation of the characters. They were presented as people subject to tensions and facing difficult decisions and dilemmas. Some contemporary commentators cited in the book even point out that socialist culture (literature, theatre, and films), instead of promoting good patterns, was presenting broken families in which the members were disturbed and there was a lack of mutual trust and understanding. At the same time, in the official language of the Party, there was a strong emphasis on individual involvement in the construction of socialism: terms such as "initiative," "commitment," and "self-determination" were often present in official speeches and party materials (Jasińska-Kania \& Siemieńska 1978: 261).

Of particular interest is Jasińska-Kania and Siemieńska's interpretation of their empirical research on attitudes, which testified to the change in basic cultural vectors in the 1970s. The research showed that as the education of the respondents increased, they attached higher importance to issues such as interesting work, dedication to others, and commitment to social issues. In turn, the lower the level of education of the respondents, the more often their attitudes could be characterised as "individualistconsumer" and desirous of "stabilisation" (Jasińska-Kania \& Siemieńska 1978: 298). Jasińska-Kania and Siemieńska demonstrated a positive interdependence between the dynamics of multi-faceted modernisation (education, standard of living, access to culture, participation in organisations) and personality. The more socialism develops, the greater the chances of creating a rich personality - complex, sensitive, and motivated to work for others. The dynamics of these two dimensions are not opposed. Individual development is not a manifestation of particularism, egoism, or bourgeois deviation. It is rather an effect and condition for the successful historical transformation that will humanise social life and bring relief to mankind from satisfying basic needs.

In the 1970s, Bauman as well - as part of redefining his critical project out of the Polish context and after his disappointment with real existing socialism - was increasingly interested in individualisation and the role of culture in the reproduction of the social order. Unlike Kołakowski, who turned to liberal-conservative positions and became one of the main intellectuals involved in the critique of totalitarianism, Bauman did not break with Marxism but subjected it to reconstruction; his aim was to preserve its utopian dimension while distancing himself from part of its theoretical apparatus.

In Socialism: Active Utopia (1976), Bauman sets a new direction for his research and engagement, which would later evolve into his widely read and 
recognised works on modernity and post-modernity. In Socialism Bauman emphasises the importance of culture in constructing the social world, and additionally of culture that places the individual at its centre. The individual is the point of reference for both the system's reproductive mechanisms, such as consumption, and for criticism of the system, as in counterculture and social movements.

This diagnosis involves departing from the belief that different levels of social reality can be explained by their reference to the production process. As far as social criticism is concerned, this shift means that not all types of social oppression can be explained by their relationship to private property and control over work. Bauman cites an example of the Holocaust as a social phenomenon that is insufficiently explained in Marxist terms. What is important for understanding the specificity of Bauman's position is his distance from the belief that the tasks of criticism entirely coincide with the goals set by new social movements and the focus on individual emancipation. He saw a double task for contemporary criticism. On the one hand, it should reveal the negative effects of consumer culture and the promise of individualisation - as in his later books on the ambivalence of postmodernism (see, for example, Bauman 1991). On the other hand, Bauman noted the specific blindness of the kind of critical thinking that focused on cultural and individual matters while omitting two important dimensions: the global differences between the centre and the periphery, and the difference between the rich and the poor within nation-states. Subsequently, Bauman wrote a whole series of books showing the brutality of social change in postmodern societies (see Bauman 1998, 2003), and promoted an ethical attitude associated with revealing social exclusion and demanding recognition for people deprived of their human dignity.

In addressing the questions of an active society, the representatives of the Warsaw School of Marxism were certainly not exceptional. They were participating in the redefinition of the general cultural framework that took place at the turn of the 1960s and 1970s on both sides of the Iron Curtain. What is specific in their reflections is reference to the Marxist tradition by linking new problems with issues of the state and development, or alienation and personality, or finally, by asking questions about the task of social criticism in changing historical conditions. The way they conducted their studies was influenced by dispositions formed within this school in the 1950s. Two things are important here. The first was their ongoing attempt to combine Marxism with empirical research. The second was that they 
thought about the possibility of social change rather within the context of existing conditions than by attempting to question the totality.

Of course, the question remains of how much Marxism was left within the Warsaw School of Marxism after 1968, when important members of the school were forced to leave Poland and on both sides of the Iron Curtain the new cultural hegemony of active society was established. It seems that with the passage of time and the changing historical context the Marxist impulse was weakening, but it is too simplistic to say that it completely disappeared. If direct references to Marx, Marxist themes (the state, development, and power), and using at least some Marxist concepts (such as alienation), are insufficient for a perspective to be recognised as Marxist, then perhaps it is worth stressing the continuity of a certain utopian Marxist heritage in the writings of the authors of the Warsaw School of Marxism. Furthermore, their conviction that existing social forms must be judged and questioned from the perspective of persons suffering exclusion should also be recalled, along with their hopes of overcoming this condition.

\section{/// Conclusion}

The achievements of the Warsaw School of Marxism remain so rich and extensive that a thorough examination would require considerable time and a huge amount of work. However, studying many thousands of pages of the books written by this narrow group of scholars is a worthwhile task both because of the value of the works themselves and because of the intellectual and political history of Central Europe.

In Hochfeld's circle, original works were created whose value came from cooperation in a rather cohesive environment. Analysis of these texts shows that the history of Marxism in Central and Eastern Europe can not be reduced to the pair "official Marxism-revisionist Marxism." There was also - to borrow the term created by Erik O. Wright and Michael Burawoy (Burawoy \& Wright 2002) - a kind of sociological Marxism, associated with efforts to deliver empirical studies on socialist societies and attempts to use that knowledge to rebuild the existing order.

An analysis of successes and failures in this respect is interesting as one kind of trajectory among the intelligentsia after the Second World War. Members of the Warsaw School of Marxism were involved in social change, but they were not radical: they were more or less close to the Party. These dispositions toward social reality have survived the collapse of so- 
cialism and manifested themselves in the attitude of Hochfeld's disciples to capitalism, which they have subjected to criticism though not absolutely rejected. There is a significant difference in the approach of the revisionist Marxists, who (with the important exception of Karol Modzelewski) rejected socialism in the 1970s, and after 1989 clearly engaged in the legitimisation of the capitalist order.

Tracking the history of the Warsaw School of Marxism provides new perspectives on the changes in post-war Poland during at least three important periods. With regard to academic and intellectual life, the period immediately after the Second World War should not be analysed through the prism of a violent break. In academia there was a high level of continuity, which defined the shape of academic life for decades to come. The history of the Warsaw School of Marxism helps us to better understand the mechanisms of Stalinism and go beyond the interpretations that limit it to phenomena within the borders of politics and religion. Finally, a good insight into the cultural dynamics of socialism in the 1970s, when individualisation and the imaginary of an active society increased in importance, can be gained from examining the writings of the school's members. Such an examination gives us a more objective view of the still-popular antitotalitarian narrative of oppressed individuals forming a civil society, and allows us to treat that vision as merely one manifestation of the profound cultural changes that constitute the genealogy of contemporaneity.

Bibliography:

/// Adorno T. W., Horkheimer M. 2002 [1947]. Dialectic of Enlightenment: Philosophical Fragments, ed. G.S. Noerr, transl. E. Jephcott, Stanford University Press.

/// Bauman Z. 1964a. Wiøje ludఇ̌kiego świata, Książka i Wiedza.

/// Bauman Z. 1964b. Zarys marksistowskiej teorii społeczeñstwa, Państwowe Wydawnictwo Naukowe.

/// Bauman Z. 1976. Socialism: An Active Utopia, George Allen \& Unwin.

/// Bauman Z. 1991. Modernity and Ambivalence, Polity Press.

/// Bauman Z. 1998. Globalization: The Human Consequences, Polity Press.

/// Bauman Z. 2003. Wasted Lives: Modernity and Its Outcasts, Polity Press. 
/// Bucholc M. 2013. "Warszawska Szkoła Historii Idei - o potrzebie porządku w historii myśli," [in:] Wokót dorobku Warszanskiej Szkoły Historii Idei, ed. A. Kołakowski, Wydawnictwo Instytutu Filozofii i Socjologii PAN, pp. $93-110$.

/// Burawoy M., Wright E.O. 2002. "Sociological Marxism,” [in:] Handbook of Sociological Theory, ed. J.H. Turner, Kluwer, pp. 193-261.

/// Chałubiński M. 1991. Polityka i socjologia. Studium koncepcji Juliana Hochfel$d a$, Wydawnictwa Uniwersytetu Warszawskiego.

/// Chałubiński M. 2007. Stanisław Ossowski, Wydawnictwo Wiedza Powszechna.

/// Collins R. 1998. Sociology of Philosophies, Harvard University Press.

/// Czarnowski S. 2015. Listy do Henri Huberta i Marcela Maussa (1905-1937), eds. K. Kończal, J. Wawrzyniak, Oficyna Naukowa.

/// Gawin D. 2013. Wielki zwrot. Ewolucja lewicy i odrodzenie idei społeczeństwa obywatelskiego 1956-1976, Znak.

/// Grochowska M. 2014. Strz̨elecki. Śladem nadziei, Świat Książki.

/// Hirszowicz M. 1964. Konfrontacje socjologiczne, Książka i Wiedza.

/// Hirszowicz M., Morawski W. 1967. Z badań nad społecznym uczestnictwem w organizacji przemystowej, Książka i Wiedza.

/// Hochfeld J. 1982a. Marksižm, socjologia, socjaližm. Wybór Pism, ed. J. Wiatr, Państwowe Wydawnictwo Naukowe.

/// Hochfeld J. 1982b [1948]. “O znaczeniu marksizmu,” [in:] J. Hochfeld, Marksižm, socjologia, socjalizm. Wybór Pism, ed. J. Wiatr, Państwowe Wydawnictwo Naukowe, pp. 51-97.

/// Hochfeld J. 1982c [1957]. “Z zagadnień parlamentaryzmu w warunkach demokracji ludowej," [in:] J. Hochfeld, Marksizm, socjologia, socjalizm. Wybór Pism, ed. J. Wiatr, Państwowe Wydawnictwo Naukowe, pp. 203-226.

/// Hochfeld J. 1982d [1963]. "Studia o marksowskiej teorii społeczeństwa," [in:] J. Hochfeld, Marksizm, socjologia, socjalizm. Wybór Pism, ed. J. Wiatr, Państwowe Wydawnictwo Naukowe, pp. 403-663. 
/// Jasińska-Kania A. 2007. "O nauce i przyjaźni," [in:] Socjologia na Uniwersytecie Warszawskim. Fragmenty historii, ed. A. Sułek, Wydawnictwo Instytutu Filozofii i Socjologii PAN, pp. 366-379.

/// Jasińska-Kania A., Siemieńska R. 1978. Wžry osobowe socjaliz̨mu, Państwowe Wydawnictwo Naukowe.

/// Kilias J. 2012. Jak socjologowie opowiadali o socjologii, Wydawnictwa Uniwersytetu Warszawskiego.

/// Kilias J. 2017. Goście ze wschodu. Socjologia Polska lat sześćdziesiatych XX wieku a nauka swiatowa, Nomos.

/// Kołakowski A. 2013. Wokót dorobku Warszanskiej Szkoty Historii Idei, Wydawnictwo Instytutu Filozofii i Socjologii PAN.

/// Kraśko N. 1996. Instytucjonalizacja socjologii w Polsce 1920-1970, Wydawnictwo Naukowe PWN.

/// Król M. 2010. Czego nas uczy Leszek Kołakonski, Wydawnictwo Czerwone i Czarne.

/// Kuroń J., Modzelewski K. 2009. “List otwarty do Partii,” [in:] J. Kuroń, Dojrzewanie. Pisma polityczne 1964-1968, eds. S. Liszka, M. Sutowski, Wydawnictwo Krytyki Politycznej, pp. 5-89.

/// Mills C.W. 1951. White Collars: The American Middle Classes, Oxford University Press.

/// Morawski W. 1970. Konflikt przemystowy w Ameryce. Praktyka, ideologia a nauka, Państwowe Wydawnictwo Naukowe.

/// Morawski W., ed. 1979. Kierowanie w społeczeństwie. Analiza socjologiczna, Państwowe Wydawnictwo Naukowe.

/// Ossowski S. 1970 [1947]. "Doktryna marksistowska na tle dzisiejszej epoki,” [in:] S. Ossowski, Drieła, vol. 6: Publicystyka, recenzje, Państwowe Wydawnictwo Naukowe, pp. 189-202.

/// Raciborski J. 2007. "Marksizm w warszawskiej socjologii uniwersyteckiej. Rozkwit i zmierzch,” [in:] Socjologia na Uniwersytecie Warszawskim. Fragmenty historii, ed. A. Sułek, Wydawnictwo Instytutu Filozofii i Socjologii PAN, pp. 239-260.

/// Schaff A. 1948. "Marksizm a rozwój nauki," Myśl Wspótczesna, vol. 6/7, pp. 245-263. 
/// Shore M. 2009. Caviar and Ashes, Yale University Press.

/// Siermiński M. 2016. Dekada przetomu. Polska lewica opozycyjna 1968-1980, Książka i Prasa.

/// Śpiewak P. 1981. "W pół drogi. Warszawska szkoła historyków idei," Wiéz, vol. 5(277), pp. 39-48.

/// Sułek A. 2011. Obrazy z życia socjologii w Polsce, Oficyna Naukowa.

/// Szacki J., ed. 1995. Sto lat socjologii polskiej: od Supińskiego do Szrczppańskiego. Wybór tekstów, Wydawnictwo Naukowe PWN.

/// Tellenback S. 1975. The Social Structure of Socialist Society: The Polish Interpretation, University of California Press.

/// Wesołowski W. 1966. Klasy, warstwy i władza, Państwowe Wydawnictwo Naukowe.

/// Wesołowski W. 1974. Rola klasy robotniczej na obecnym etapie, Instytut Wydawniczy CRZZ.

/// Wiatr J. 1968 [1966]. Cay zmierzch ery ideologii? Problemy polityki i ideologii w śmiecie wspótcresnym, $2^{\text {nd }}$ ed., Książka i Wiedza.

/// Wiatr J. 1969. Naród i państwo. Socjologiczne problemy kwestii narodowej, Książka i Wiedza.

/// Wiatr J. 1973a. Spoleczeństwo, polityka, nauka, Książka i Wiedza.

/// Wiatr J. 1973b. "Juliana Hochfelda marksizm otwarty," Studia Socjologiczne, vol. 4(51), pp. 47-63.

/// Wiatr J. 2017. “Otwarty marksizm i odrodzenie socjologii: rola Juliana Hochfelda i Zygmunta Baumana," Studia Socjologiczno-Polityczne, vol. 1(6), pp. 13-25.

/// Woleński J. 1989. Logic and Philosophy in the Lvov-Warsaw School, Kluwer.

\section{/// Abstract}

This article concerns the Warsaw School of Marxism, which was created at the University of Warsaw after the Second World War and functioned simultaneously with the famous Warsaw School of the History of Ideas. 
The Warsaw School of Marxism was formed in the circle of Julian Hochfeld, a pre-war socialist who not only wanted to bring Marxism into the social sciences and culture in Poland but also to redefine it in order to use it to analyse socialist societies. Inspired by Hochfeld's ideas, his pupils - including Zygmunt Bauman, Włodzimierz Wesołowski, Maria Hirszowicz, Jerzy Wiatr, Witold Morawski, and Aleksandra Jasińska-Kania - engaged in original reflection and research. Some of their studies came to be seen as milestones for sociology in Poland. The history of the school is presented here in the context of the social and political changes occurring in the Polish People's Republic: Stalinism, the "Polish Way to Socialism" after 1956, and the breakthrough between the 1960s and 1970s. The history of the school is interesting in itself and can also serve to further an understanding of the dynamics of "real socialist" societies within the framework of totalitarianism.

Keywords:

The Warsaw School of Marxism, sociology, "real socialist" societies

/// Maciej Gdula - sociologist, works as associate professor at the Institute of Sociology, University of Warsaw. His main fields of interest are social classes and sociological theory. He published among others: Style $\dot{z}$ ycia i porzqdek klasowy w Polsce [Life-styles and Class Order in Poland] with Przemysław Sadura (2012) and Uspotecznienie i kompozycja. Dwie tradycje myśli spotecznej a wspótczesne teorie kerytyczne [Sociation and Composition: Two Traditions of Social Thought and Contemporary Critical Theory] (2015).

Email: gdulam@is.uw.edu.pl 
